\title{
Hyaluronate Activation of CD44 Induces Insulin-like Growth Factor-1 Expression by a Tumor Necrosis Factor- $\alpha$-dependent Mechanism in Murine Macrophages
}

Paul W. Noble, *5 Fiona R. Lake, * Peter M. Henson, *8 and David W. H. Riches *

Division of Basic Sciences, Departments of ${ }^{*}$ Pediatrics and ${ }^{\ddagger}$ Medicine, National Jewish Center for Immunology and Respiratory

Medicine, Denver, Colorado 80206; and ${ }^{\S}$ Division of Pulmonary Sciences, Departments of Medicine and "Biochemistry, Biophysics, and Genetics, University of Colorado Health Sciences Center, Denver, Colorado 80262

\begin{abstract}
Macrophages participate in inflammatory and repair processes in part through the selective release of cytokines that contribute to tissue remodeling. Extracellular matrix components generated at inflammatory sites may influence tissue remodeling by effects on leukocyte adherence and local cytokine production. In murine bone marrow-derived macrophages, we found that soluble hyaluronic acid stimulated IL-1 $\beta$, TNF $\alpha$, and insulin-like growth factor-1 (IGF-1) mRNA transcript expression as well as IGF-1 protein synthesis. Monoclonal antibodies to the hyaluronic acid receptor CD44 blocked the effects of hyaluronic acid on IL-1 $\beta$, TNF $\alpha$, and IGF-1 expression. TNF $\alpha$ and IL-1 $\beta$ mRNA expression preceded IGF-1 protein synthesis, and TNF $\alpha$, but not IL-1 $\beta$, was found to directly stimulate IGF1. Furthermore, IGF-1 induction was dependent on endogenous TNF $\alpha$ production since IGF-1 protein synthesis was inhibited in the presence of anti-TNF $\alpha$ antiserum. In addition, IL-1 $\beta$ was found to exert a regulatory role on IGF-1 production by enhancing the TNF $\alpha$ effect. IL-1 $\beta$ and TNF $\alpha$ mRNA transcript expression as well as IGF-1 protein synthesis were also stimulated by chrysotile asbestos. Anti-CD44 antibodies had no effect whereas anti-TNF $\alpha$ antiserum blocked asbestosstimulated IGF-1 production. These results indicate that hyaluronate activation of CD44 induces cytokine expression and macrophage-derived IGF-1 production is dependent on TNF $\alpha$ expression. (J. Clin. Invest. 1993.91:2368-2377.) Key words: extracellular matrix • cytokine • gene expression • inflammation - adhesion molecules
\end{abstract}

\section{Introduction}

Macrophages maintain essential roles in the inflammatory and repair processes associated with tissue injury through the ability to exercise diverse functions, including phagocytosis and release of proteases, cytokines, mesenchymal growth factors, and other mediators (1). Recent studies have provided compelling evidence that a major product of activated macrophages, TNF $\alpha$, is involved in the pathogenesis of both pulmo-

Address correspondence to Dr. Paul W. Noble, Division of Pulmonary and Critical Care Medicine, Department of Medicine, Johns Hopkins University School of Medicine, 858 Ross Research Building, 720 Rutland Avenue, Baltimore, MD 21205-2196.

Received for publication 30 September 1992 and in revised form 5 January 1993.

J. Clin. Invest.

(C) The American Society for Clinical Investigation, Inc.

$0021-9738 / 93 / 06 / 2368 / 10 \$ 2.00$

Volume 91, June 1993, 2368-2377 nary granulomatous inflammation and fibrosis (2-4). The mechanisms by which TNF $\alpha$ promotes granuloma formation and fibrosis have not been elucidated but a likely possibility is through the generation of growth factors that stimulate fibroblast proliferation and collagen deposition. One such growth factor that has been implicated in pulmonary fibrosis is insulinlike growth factor-1 (IGF-1 $)^{1}$ (5). IGF-1/somatomedin-C is a mitogenic polypeptide with structural homology to proinsulin and mediates many of the growth-promoting effects of growth hormone (6). IGF-1 can serve as a progression-type growth factor for fibroblast proliferation, allowing competent cells to move through $G_{1}$ and synthesize DNA (7). Bitterman and colleagues (8) isolated a progression-type fibroblast growth factor in bronchoalveolar lavage fluid from patients with pulmonary fibrosis that was later identified as a 25-kD IGF-1-type molecule (5). The mature circulating plasma form of IGF-1 produced in the liver is $7.5 \mathrm{kD}(6)$. Higher molecular mass (21-25 kD) "tissue forms" of IGF-1 have also been identified from cultured smooth muscle cells and fibroblasts (6). Recently, human peripheral monocytes have been shown to produce a 14-kD form of IGF-1 (9). Macrophages exposed in vitro to stimuli that cause pulmonary fibrosis in vivo, such as chrysotile asbestos, have been shown to release IGF-1 protein into conditioned media (5). In addition, chrysotile asbestos increases IGF-1 mRNA expression in murine bone marrow-derived macrophages (BMDM) (10). IGF-1 also has been shown to stimulate hematopoeisis and the murine bone marrow stromal cell line TC-1 has been shown to secrete IGF-1 (11).

In addition to the secretion of inflammatory cytokines, macrophages also release numerous proteases that degrade components of the extracellular matrix (12). Several components of extracellular matrix have been demonstrated in the bronchoalveolar lavage fluid from inflammatory lung lesions, including fibronectin (13), collagen fragments (14), and the glycosaminoglycan, hyaluronic acid (14-16). Hyaluronate production has been shown to precede the tissue fibrotic response and is present in both the alveolar and interstitial spaces $(15,16)$. The generation of matrix molecules may be due to proteolytic cleavage of existing structures and/or de novo synthesis $(12,17)$. Matrix components have been shown to interact with cell surface adhesion molecules on leukocytes, which may be important in directing cellular traffic $(18,19)$. In addition to promoting adhesion, recent data have indicated that ligation of adhesion molecules such as the fibronectin receptor activate signal transduction pathways, resulting in the induction of inflammatory gene expression (20). Recently, it has been established that the cell surface adhesion molecule CD44 is the principal

1. Abbreviations used in this paper: BMDM, bone marrow-derived macrophages; dpm, disintegrations per minute; GAPDH, glyceraldehyde 3-phosphodehydrogenase; IGF, insulin-like growth factor. 
receptor for hyaluronic acid in mouse and human $(21,22)$. CD44 has been implicated in lymphocyte homing, embryonic development, $\mathrm{T}$ cell activation, and neoplastic transformation and metastasis $(18,23)$. CD44 is also expressed on monocyte/ macrophages and is identical or closely related to the previously described 85-95-kD murine phagocytic glycoprotein-1 (Pgp-1)/Ly-24, Hermes antigens, ECM-III receptor, p85, and In ( $\mathrm{Lu})$-related p80 $(18,24,25)$. Exposure of monocytes to surface-bound CD44 monoclonal antibodies results in the release of IL- $1 \beta$, TNF $\alpha$, and macrophage colony-stimulating factor (M-CSF) protein (26-28). Together, these studies suggest the possibility that in addition to facilitating cell migration, hyaluronic acid may be a physiological stimulus for macrophage cytokine and growth factor production by interacting with CD44.

This study was designed to examine the hypothesis that extracellular matrix components known to be generated during an inflammatory response stimulate macrophage cytokine and growth factor production. The results show that soluble hyaluronic acid induces IL- $1 \beta$, TNF $\alpha$, and IGF- 1 expression. IGF1 induction is mediated by CD44 and is dependent on endogenous TNF $\alpha$ production. TNF $\alpha$ production appears to be critical for IGF-1 synthesis since chrysotile asbestos induction of IGF-1 is also blocked by anti-TNF $\alpha$ antiserum. Together, these data support the hypothesis that extracellular matrix components induce cytokine and growth factor gene expression and hyaluronic acid/CD44-macrophage interactions may represent an important mechanism in regulating the inflammatory and fibrotic tissue response.

\section{Methods}

Animals. C3H/HeJ mice were obtained from The Jackson Laboratory (Bar Harbor, ME). All mice were females and 8 wk of age. The $\mathrm{C} 3 \mathrm{H} /$ HeJ strain is LPS hyporesponsive and was chosen to eliminate the effects of trace LPS contamination. The mice were killed by $\mathrm{CO}_{2}$ narcosis.

Reagents. DME was obtained from Hazelton Research Products (Denver, PA). FBS was purchased from Irvine Scientific (Irvine, CA). Trans-label containing L- $\left[{ }^{35} \mathrm{~S}\right]$ methionine $(>1,000 \mathrm{Ci} / \mathrm{mmol})$ and $\left[{ }^{32} \mathrm{P}\right]-\alpha$-dCTP $(>3,000 \mathrm{Ci} / \mathrm{mmol})$ were obtained from ICN Biomedicals, Inc. (Costa Mesa, CA). "Immunoprecipitin," a Formalin-fixed preparation of Staphylococcus aureus, was purchased from Bethesda Research Laboratories (Gaithersburg, MD). Rabbit anti-human IGF1 antibodies were obtained from Drs. L. Underwood and J. J. Van Wyk via the Hormone Distributions Programs of the National Institute of Diabetes and Digestive and Kidney Diseases and used at a final dilution of 1:100. Rat monoclonal antibodies to Pgp-1/CD44 (KM201 hybridoma) have been previously described and were generously provided by Dr. P. W. Kincade (25). Hybridoma supernatant was used at a final concentration of $10 \mu \mathrm{g} / \mathrm{ml}$. Murine IL- $1 \beta$ and polyclonal rabbit anti-murine IL- $1 \beta$ antiserum were obtained from R\&DSys., Inc. (Minneapolis, MN). Murine TNF $\alpha$ and polyclonal rabbit anti-TNF $\alpha$ antiserum $(10,000$ neutralizing units $/ \mathrm{ml})$ were obtained from Genzyme Corp. (Boston, MA). Hyaluronic acid (hyaluronate; catalog H-4015), heparin, heparan sulfate, and chondroitin sulfate $A$ were obtained from Sigma Chemical Co. (St. Louis, MO). Chrysotile asbestos was obtained courtesy of Dr. A. Brody (National Institute of Environmental Health Sciences). Rat and rabbit IgG $(25 \mu \mathrm{g} / \mathrm{ml})$ was obtained from Cappel Laboratories (West Chester, PA).

Isolation and culture of BMDM. Murine BMDM were obtained using a technique previously described (29). DME containing $2 \mathrm{mM}$ glutamine, $100 \mathrm{U} / \mathrm{ml}$ penicillin, $100 \mu \mathrm{g} / \mathrm{ml}$ streptomycin, $0.37 \%$ (wt/ vol) $\mathrm{NaHCO}_{3}, 10 \%$ (vol/vol) heat-inactivated FCS, and $10 \%$ (vol/ vol) L929 cell-conditioned medium as a source of CSF-1 was used for the isolation, culture, and stimulation of the BMDM. Bone marrow cells were flushed asceptically from the dissected pelvises, femurs, and tibias of $\mathrm{C} 3 \mathrm{H} / \mathrm{HeJ}$ mice with a jet of complete medium directed through a 25-gauge needle to form a single cell suspension. The bone marrow cells were dispensed at a concentration of $9 \times 10^{5}$ cells per well in 12-well tissue (22-mm diameter) culture plates for experiments using biosynthetic labeling, or $10^{7}$ cells per $100-\mathrm{mm}$ diameter culture dishes for RNA analysis. The cells were maintained at $37^{\circ} \mathrm{C}$ under a $10 \%$ ( vol $/ \mathrm{vol}$ ) $\mathrm{CO}_{2}$ atmosphere for $5 \mathrm{~d}$. Thereafter, the medium was changed on alternate days until the cells were used between days 6 and 8. There was no evidence to suggest aggregation of cells either by light or electron microscopy (data not shown). The monolayers were $98 \%$ esterase positive and $98 \%$ of the cells were phagocytic for latex particles. The macrophage monolayers were washed with DME at $37^{\circ} \mathrm{C}$ before stimulation in duplicate (three wells were combined into two) as described in Results. For experiments to evaluate priming, pretreatment with IL- $1 \beta$ was for $3 \mathrm{~h}$, the cells were then rinsed with DME before addition of TNF $\alpha$.

Quantification of IGF-1 synthesis. Macrophage monolayers were pulse labeled with $100 \mu \mathrm{Ci}$ of $\left[{ }^{35} \mathrm{~S}\right]$ methionine for $1 \mathrm{~h}$ and then lysed in $1 \mathrm{ml}$ of a solution composed of $0.5 \%$ Triton X-100 (vol/vol), $2 \mathrm{mM}$ PMSF, $0.25 \%$ (wt/vol) sodium deoxycholate, $10 \mathrm{mM}$ EDTA, and 10 $\mu \mathrm{g} / \mathrm{ml}$ leupeptin dissolved in phosphate-buffered saline, $\mathrm{pH} 7.4$, as previously described (29). The lysates were precleared with $200 \mu \mathrm{l}$ of Immunoprecipitin for $30 \mathrm{~min}$ before adding SDS to a final concentration of $0.1 \%(\mathrm{wt} / \mathrm{vol})$. After overnight incubation at $4^{\circ} \mathrm{C}$, the immune complexes containing the IGF-1 antigen were adsorbed to Immunoprecipitin, washed once with $0.9 \mathrm{ml}$ of ice-cold wash solution composed of $0.5 \%$ ( vol $/ \mathrm{vol}$ ) Triton X-100, $0.25 \%(\mathrm{wt} / \mathrm{vol}$ ) sodium deoxycholate, $0.1 \%$ (wt $/ \mathrm{vol}$ ) SDS, and $5 \mathrm{mg} / \mathrm{ml}$ BSA dissolved in PBS, $\mathrm{pH}$ 7.4 , and then washed three times with the same solution without BSA. After the final wash, the Immunoprecipitin was pelleted in a microfuge for $5 \mathrm{~min}$ and the pellet was solubilized in $15 \mu \mathrm{l}$ of Laemmli sample buffer. The radiolabeled IGF-1 was separated by SDS-PAGE through a $15 \%(\mathrm{wt} / \mathrm{vol})$ polyacrylamide gel under reducing conditions. The gel was dried and the radioactive bands were localized by fluorography. The major radioactive band $(\sim 16-17 \mathrm{kD})$ was cut out, hydrolyzed in $15 \%$ ( vol/ vol $) \mathrm{H}_{2} \mathrm{O}_{2}$, and quantified by liquid-scintillation spectrometry. The analysis of incorporation of $\left[{ }^{35} \mathrm{~S}\right]$ methionine into total TCAprecipitable protein to normalize the data for total protein synthesis was determined by precipitation with $10 \%$ (wt/vol) ice-cold TCA on filter paper discs as previously described (29). The results were expressed as the dpm incorporated into IGF- 1 per $10^{7} \mathrm{dpm}$ of TCA-precipitable protein. Individual experiments were conducted in duplicate a minimum number of three times.

Quantification of $m R N A$ transcripts. The expression of IL- $1 \beta$, TNF $\alpha$, and IGF-1 mRNA transcripts were determined by Northern analysis. The extraction, purification, electrophoresis, and transfer of the RNA to nylon filters were carried out as described (29). In brief, macrophage monolayers were extracted with $4 \mathrm{M}$ guanidine isothiocyanate and the RNA was purified by centrifugation through $5.7 \mathrm{M}$ cesium chloride at $100,000 \mathrm{~g}$ for $18 \mathrm{~h}(30) .15 \mu \mathrm{g}$ of total RNA was subjected to electrophoresis under denaturing conditions through a $1.2 \%$ agarose-formaldehyde gel and then transferred to NYTRAN ${ }^{\circ}$ hybridization filters $(31)$. The blots were baked at $80^{\circ} \mathrm{C}$ for $1 \mathrm{~h}$ in a vacuum oven. The blots were hybridized with $10^{6} \mathrm{dpm} / \mathrm{ml}$ of ${ }^{32} \mathrm{P}$-labeled cDNA probes for $18 \mathrm{~h}$, washed to a final stringency of $0.2 \times \mathrm{SSC}$, and autoradiograms prepared by exposure to Kodak XAR film at $-70^{\circ} \mathrm{C}$. The murine IGF-1 cDNA probe was obtained from Dr. Peter Rotwein (Washington University, St. Louis, MO). The murine IL-1 $\beta$ and TNF $\alpha$ cDNAs were obtained from Dr. Arjin Singh (Genentech, Inc., South San Francisco, CA). To ensure that the differences in transcript expression were not due to differential loading of RNA, the blots were stripped and reprobed with human glyceraldehyde 3-phosphodehydrogenase (GAPDH) cDNA. The density of the autoradiographic signals were quantified by scanning densitometry combined with integration using software (Image 1.35; Image Processing Software, Inc., Madison, WI) run on a Macintosh II microcomputer. The results were 
expressed as a ratio of IGF-1 to GAPDH expression as indicated and are representative of at least three experiments.

Data analysis. Results are presented as the mean \pm standard error of the mean for three or more separate experiments each performed in duplicate. Comparisons between groups were made using the Student's paired $t$ test.

\section{Results}

Hyaluronic acid stimulates murine macrophage-derived IGF$1 \mathrm{mRNA}$ expression and protein synthesis. Murine BMDM were exposed to soluble hyaluronic acid and de novo IGF-1 protein synthesis was quantified by immunoprecipitation of ${ }^{35} \mathrm{~S}$-radiolabeled protein, which revealed a $16-17-\mathrm{kD}$ band on polyacrylamide gel under reducing conditions (Fig. $1 A$ ). As seen in Fig. $1 B$, a dose-dependent increase in IGF-1 protein synthesis was observed over a hyaluronic acid concentration range of $1 \mu \mathrm{g} / \mathrm{ml}$ to $1 \mathrm{mg} / \mathrm{ml}$. There is constitutive synthesis of IGF-1 protein that increased fourfold at $1 \mathrm{mg} / \mathrm{ml}$ of hyaluronic acid. Fig. $1 C$ demonstrates the time course for IGF-1 protein synthesis after incubation with $1 \mathrm{mg} / \mathrm{ml}$ of hyaluronic acid. IGF- 1 synthesis peaked at $18 \mathrm{~h}$, remained elevated at $24 \mathrm{~h}$, and by $36 \mathrm{~h}$ was nearly returned to baseline. To determine the level of IGF-1 induction, Northern analysis was performed on total RNA isolated from macrophages stimulated with $1 \mathrm{mg} / \mathrm{ml}$ of hyaluronic acid at various times up to $48 \mathrm{~h}$. Fig. 2 illustrates a twofold increase at $12 \mathrm{~h}$ in steady-state IGF-1 mRNA levels above a substantial constitutive level.

Effects of hyaluronic acid on TNF $\alpha$ and IL-1 $\beta$ mRNA transcript expression. Previously it has been shown that human peripheral monocytes and rabbit peritoneal macrophages release IL-1-like activity in response to soluble hyaluronic acid (32). To determine if cytokine gene induction was a primary response to hyaluronic acid, total RNA was isolated from stimulated macrophages at various time intervals. As illustrated in Fig. 3, both TNF $\alpha$ and IL- $1 \beta$ mRNA transcripts were markedly induced early after exposure to hyaluronic acid. In fact, TNF $\alpha$ mRNA was strongly induced at $1 \mathrm{~h}$. IL- $1 \beta$ was also induced early, but the peak was slightly later than that for TNF $\alpha$. Of note, the TNF $\alpha$ and IL- $1 \beta$ mRNA induction were maximal at earlier time points in relation to IGF-1 protein synthesis (Fig. $1 C$ ), suggesting to us the possibility that cytokine production may be involved in regulating the subsequent growth factor production. Before addressing that hypothesis,

A

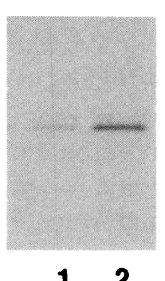

$-17 \mathrm{kD}$

12

B

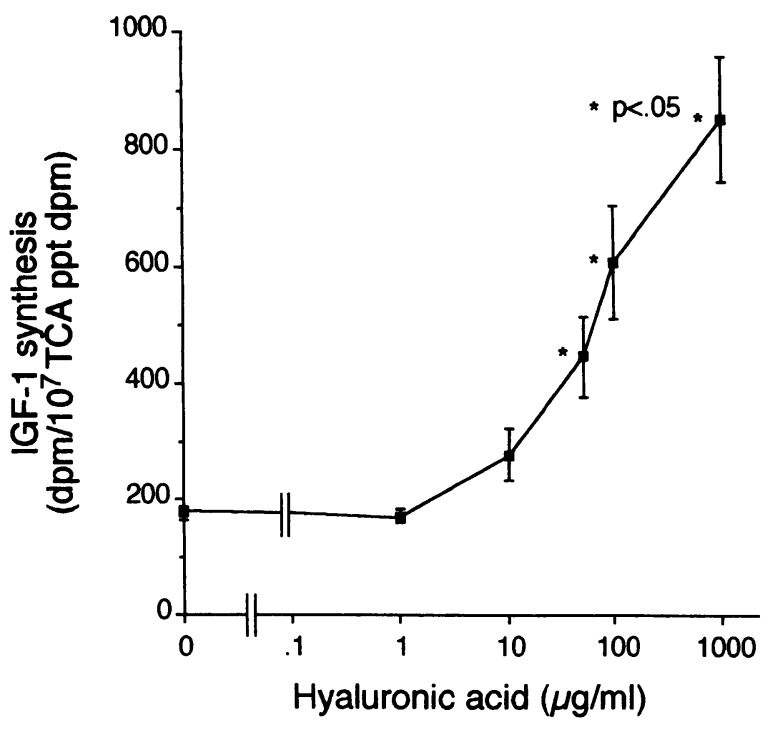

C

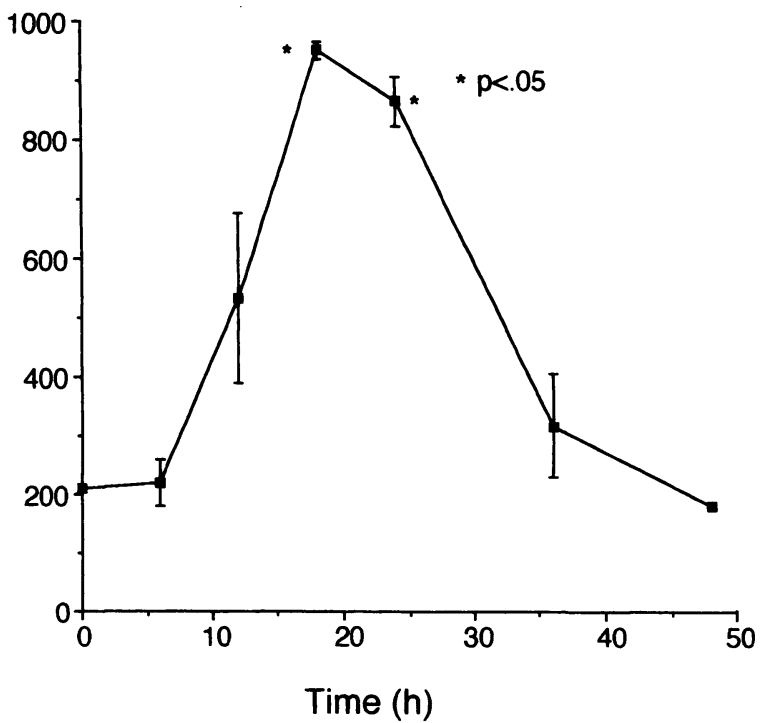

Figure 1. Murine BMDM synthesize IGF-1 in response to increasing concentrations of soluble hyaluronic acid. IGF-1 synthesis was quantitated by immunoprecipitation of $\left[{ }^{35} \mathrm{~S}\right]$ methionine biosynthetically labeled cells with specific antibody. $(A)$ Autoradiograph of a representative $15 \%$ polyacrylamide gel run under reducing conditions. $(B)$ Macrophages were incubated with the indicated concentrations of hyaluronic acid for $18 \mathrm{~h}$. The results are expressed in relation to total protein synthesis as determined by the TCA-precipitable fraction. Results are from four experiments. $(C)$ Time course for macrophage IGF-1 protein synthesis. Macrophages were incubated with $1 \mathrm{mg} / \mathrm{ml}$ of hyaluronic acid. Results are from three experiments. 


\section{$\begin{array}{lllllll}0 & 3 & 6 & 12 & 24 & 36 & 48\end{array}$}

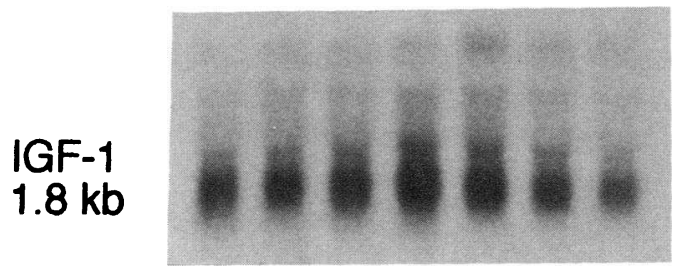

GAPDH
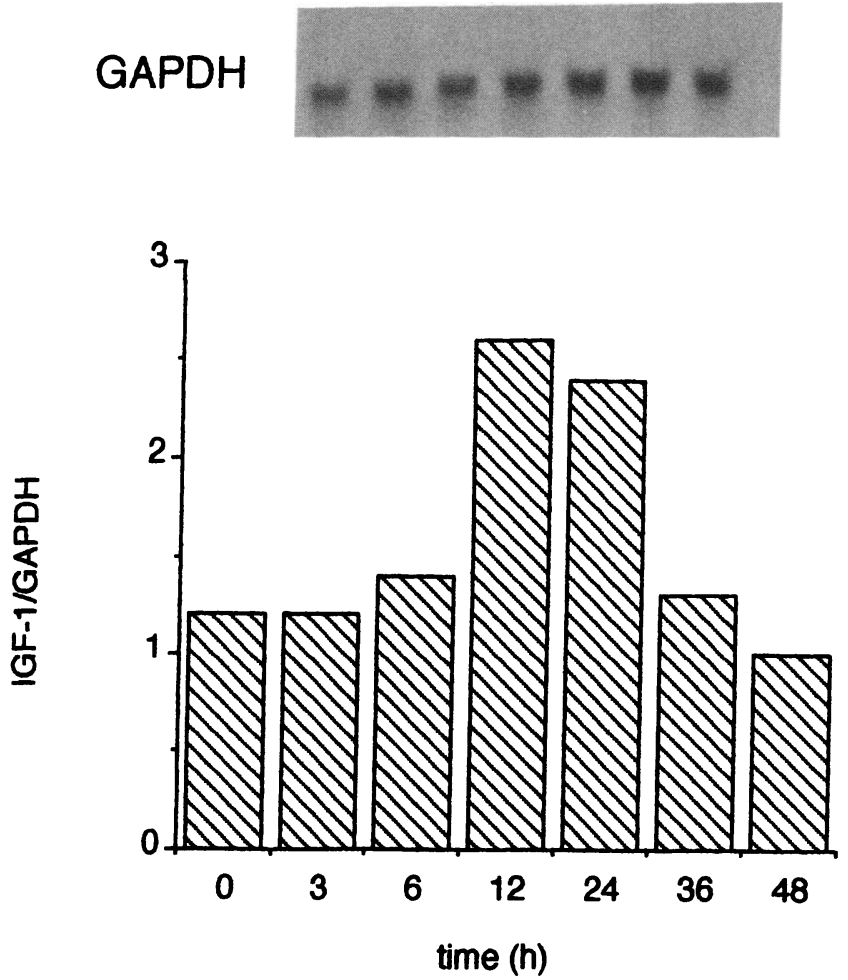

Figure 2. Autoradiograph of a Northern blot demonstrating increased expression of IGF-1 mRNA transcripts in macrophages stimulated with $1 \mathrm{mg} / \mathrm{ml}$ of hyaluronic acid over the indicated time intervals. At the indicated time intervals, $15 \mu \mathrm{g}$ per lane of total RNA was isolated and subjected to $1.2 \%$ agarose-formaldehyde gel electrophoresis, transferred onto nytran membrane, and probed with ${ }^{32} \mathrm{P}$-labeled murine IGF- $1 \mathrm{cDNA}$ at $10^{6} \mathrm{dpm} / \mathrm{ml}$. The blots were then stripped and reprobed with ${ }^{32} \mathrm{P}$-labeled GAPDH cDNA to demonstrate equal loading of mRNA. The results are expressed as a ratio of the densitometry units for IGF-1 and GAPDH as described in Methods. This is a representative example of three similar experiments.

we first wanted to determine if the macrophage response to hyaluronic acid was specific or whether related glycosaminoglycans could also initiate cytokine gene expression. In addition, experiments were performed to determine whether the cell surface adhesion molecular CD44 (the principal cell surface receptor for hyaluronic acid) was involved in mediating the effects of hyaluronic acid.

Stimulation of $T N F \alpha, I L-1 \beta$, and IGF-1 is specific for hyaluronic acid and is blocked by anti-Pgp-1/CD44 monoclonal antibodies. Macrophages were incubated with soluble structurally related glycosaminoglycans to provide some assessment of specificity for hyaluronic acid. Fig. 4 demonstrates that at the high concentration of $1 \mathrm{mg} / \mathrm{ml}$ there was no significant increase in IGF-1 protein synthesis in response to heparan sul- fate, heparin, or chondroitin sulfate A. In addition, chondroitin sulfate A did not induce IL- $1 \beta$ mRNA transcript expression (data not shown). To determine whether hyaluronic acid was inducing cytokine gene expression by activating the cell surface receptor $\mathrm{CD} 44$, macrophages were exposed to hyaluronic acid in the presence of $10 \mu \mathrm{g} / \mathrm{ml}$ of anti-Pgp-1/CD44 monoclonal antibodies (KM 201). As demonstrated in Fig. $5 A$, IGF-1 protein synthesis was blocked when macrophages were pretreated with KM 201 antibodies but not pooled rat IgG. Of note, KM 201 antibodies alone did not demonstrate agonist activity as has been observed for other anti-CD44 monoclonal antibodies (33). To further delineate the relationship between CD44 and macrophage gene expression, cells were stimulated with hyaluronic acid in the presence of KM 201 antibodies, and the effect on IL- $1 \beta$ and TNF $\alpha$ mRNA expression was determined. Fig. $5 B$ shows that KM 201 antibodies also inhibit hyaluronic acid-induced cytokine mRNA expression. Thus, hyaluronic acid stimulation of IL- $1 \beta, \mathrm{TNF} \alpha$, and IGF-1 appears to be mediated by CD44.

Effects of IL-I $\beta$ and TNF $\alpha$ on macrophage-derived IGF-1 production. The observation that TNF $\alpha$ and IL- $1 \beta$ mRNA expression preceded both IGF-1 mRNA and protein production suggested the possibility that the cytokines may be involved in regulating the pathway leading to IGF-1 production. To test this hypothesis, we first determined if TNF $\alpha$ or IL- $1 \beta$ exhibited direct effects on IGF-1 production. Fig. 6 shows the effects of increasing concentrations of TNF $\alpha$ and IL-1 $\beta$ on IGF-1 protein synthesis. IL- $1 \beta$ had no significant effect whereas TNF $\alpha$ stimulated IGF-1 synthesis. When macrophages were stimulated with $10 \mathrm{ng} / \mathrm{ml}$ of TNF $\alpha$, there was nearly a sixfold increase in IGF-1 synthesis. At least a portion of the stimulatory
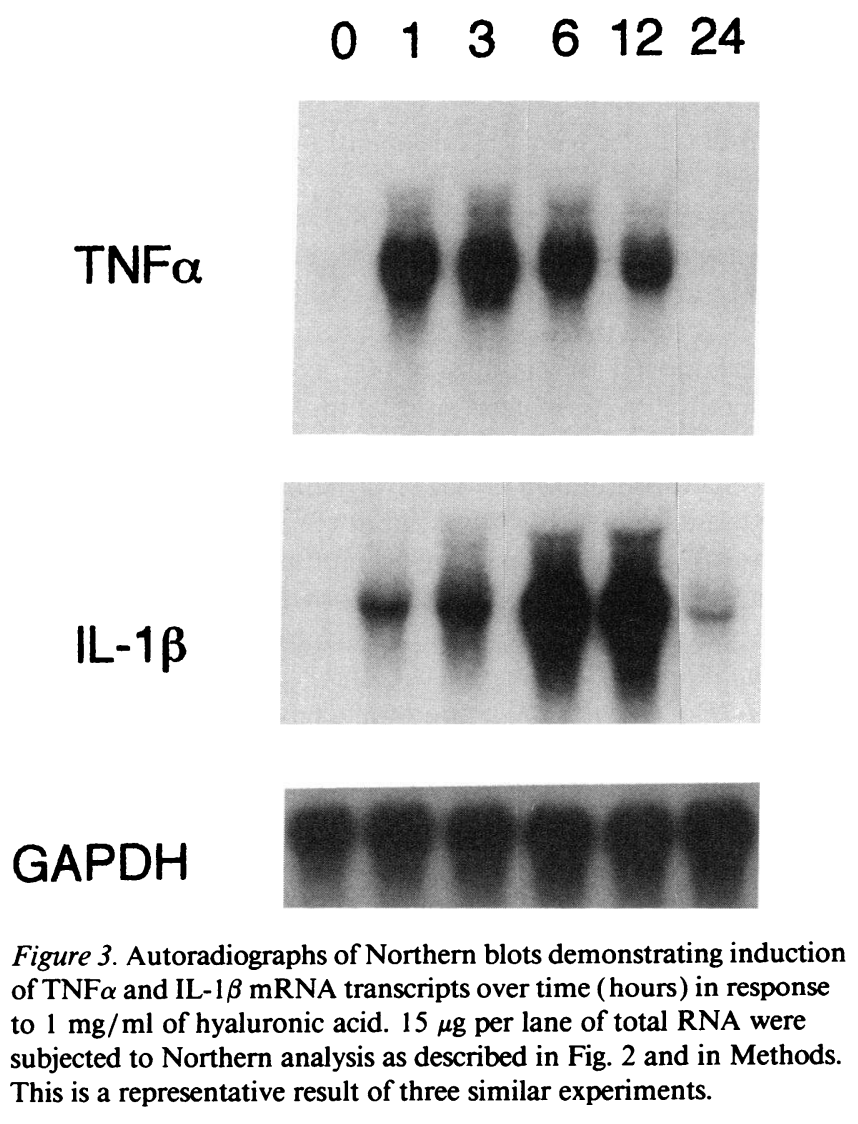


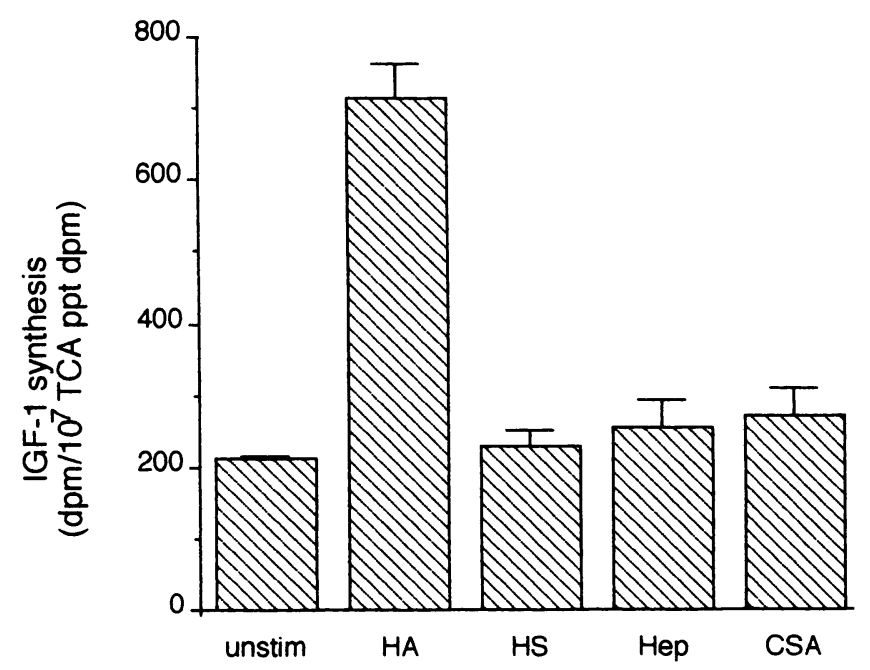

Figure 4. Hyaluronic acid but not related glycosaminoglycans stimulate macrophage IGF-1 protein synthesis. Macrophages were incubated with media (unstim), hyaluronic acid $(H A)$, heparan sulfate $(H S)$, heparin $(H e p)$, and chondroitin sulfate A (CSA). All stimuli were used at a concentration of $1 \mathrm{mg} / \mathrm{ml}$ and the incubation time was $18 \mathrm{~h}$.

effect of TNF $\alpha$ occurred at the transcript level since steadystate IGF-1 mRNA levels were increased over twofold in response to $10 \mathrm{ng} / \mathrm{ml}$ (Fig. 7). IL- $1 \beta$ and TNF $\alpha$ are known to exhibit overlapping functions, as well as to act synergistically (34). To determine if IL- $1 \beta$ influenced the effect of TNF $\alpha$ on IGF-1 synthesis, macrophages were pretreated with $10 \mathrm{ng} / \mathrm{ml}$ of IL- $1 \beta$ for $3 \mathrm{~h}$ before exposure to TNF $\alpha$. Fig. 8 shows that IL- $1 \beta$ enhanced TNF $\alpha$-stimulated IGF- 1 synthesis over a 100fold concentration range of TNF $\alpha$. In fact, pretreatment with IL- $1 \beta$ effectively primed the cells to respond to TNF $\alpha$ at a concentration of TNF $\alpha$ that alone did not stimulate IGF-1 in unprimed cells.

Endogenous $T N F \alpha$ but not $I L-1 \beta$ is required for hyaluronic acid to stimulate IGF-1 production. We have shown that TNF $\alpha$ and IL- $1 \beta$ are induced early after stimulation with hyaluronic acid (Fig. 3) and that TNF $\alpha$ directly stimulates IGF-1 (Fig. 6). To determine if TNF $\alpha$ and IL- $1 \beta$ play a role in regulating IGF1 production, macrophages were stimulated with hyaluronic acid in the presence of anti-TNF $\alpha$ or anti-IL- $1 \beta$ antisera. Hyaluronic acid stimulation of IGF-1 protein synthesis is inhibited in the presence of anti-TNF $\alpha$, but not anti-IL- $1 \beta$ antisera (Fig. 9). Anti-IL- $1 \beta$ antisera ( $25 \mu \mathrm{g} / \mathrm{ml})$ inhibited priming with recombinant murine IL-1 $\beta$ (data not shown). Thus, endogenous TNF $\alpha$, but not IL- $1 \beta$ production is critical for IGF- 1 synthesis.

The role of TNF $\alpha$ and CD44 in chrysotile asbestos-stimulated IGF-1 synthesis. We and others have shown that chrysotile asbestos fibers stimulate IGF- 1 mRNA expression and protein release in murine and human macrophages $(5,10)$. Asbestos has also been shown to stimulate macrophages to release TNF activity (35). We used the ability of asbestos to stimulate IGF-1 production to determine if CD44 and TNF $\alpha$ were necessary components in the signal transduction pathway leading to IGF-1 synthesis. Fig. $10 A$ shows that chrysotile asbestos induced both IL- $1 \beta$ and TNF $\alpha$ mRNA transcripts in murine BMDM. When macrophages were stimulated with chrysotile asbestos at a concentration of $50 \mu \mathrm{g} / \mathrm{ml}$ for $18 \mathrm{~h}$, there was an

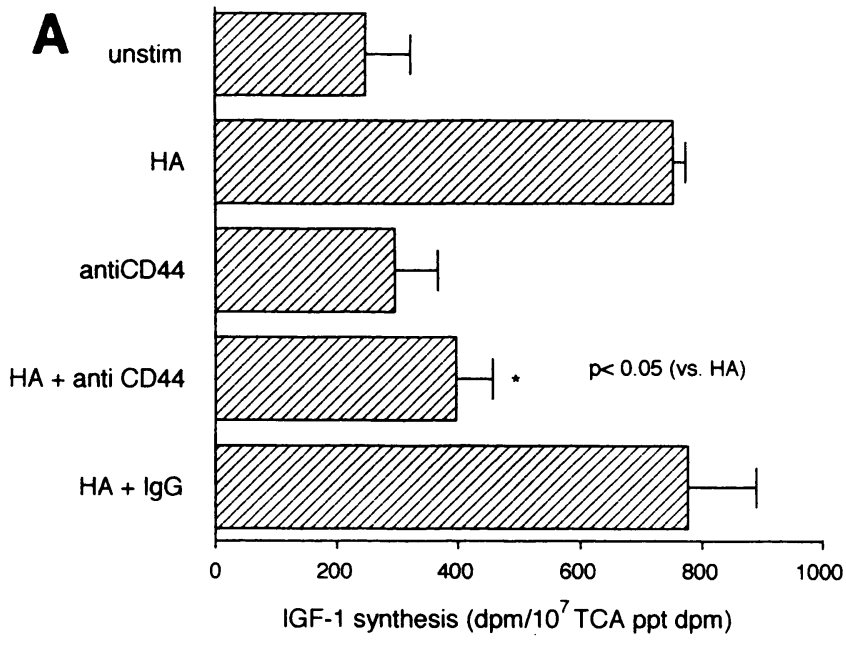

B
$\mathrm{IL}-1 \beta$

GAPDH

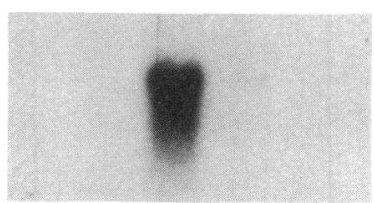

\section{TNF $\alpha$}
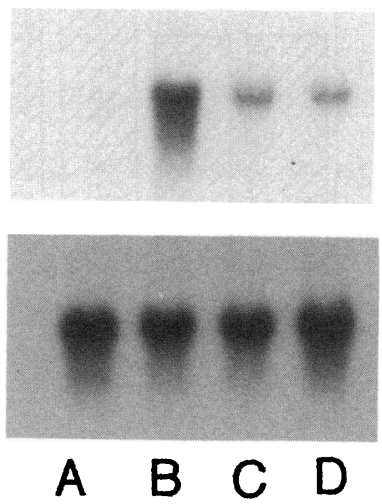

Figure 5. (A) Anti-CD44 monoclonal antibodies inhibit hyaluronic acid stimulation of macrophage IGF-1. Macrophages were incubated with media ( unstim), hyaluronic acid (HA), anti-Pgp-1/CD44 monoclonal antibodies $(10 \mu \mathrm{g} / \mathrm{ml})$, hyaluronic acid $(1 \mathrm{mg} / \mathrm{ml})$ + anti-Pgp-1/CD44 monoclonal antibodies $(10 \mu \mathrm{g} / \mathrm{ml})$, or hyaluronic acid + rat $\operatorname{IgG}(25 \mu \mathrm{g} / \mathrm{ml})$. Pretreatment with anti-Pgp-1/ $\mathrm{CD} 44$ monoclonal antibodies was for $30 \mathrm{~min}$ at $37^{\circ} \mathrm{C}$. Incubation was for $18 \mathrm{~h}$ and IGF-1 protein synthesis was quantitated by immunoprecipitation of $\left[{ }^{35} \mathrm{~S}\right]$ methionine biosynthetically labeled cells as described in Fig. 1 and in Methods. Results are from four experiments. The $P$ value refers to the comparison between HA and HA + antiCD44 antibodies. (B) Autoradiographs of Northern blots demonstrating that anti-CD44 monoclonal antibodies inhibit hyaluronic acid stimulation of macrophage IL- $1 \beta$ and TNF $\alpha$ mRNA expression. Macrophages were stimulated for $3 \mathrm{~h}$ under the following conditions: (lane $A$ ) media alone; (lane $B$ ) hyaluronic acid $(1 \mathrm{mg} / \mathrm{ml}$ ); (lane $C$ ) hyaluronic acid $(1 \mathrm{mg} / \mathrm{ml})+$ anti-Pgp-1/CD44 monoclonal antibodies $(10 \mu \mathrm{g} / \mathrm{ml})$; and (lane $D)$ anti-Pgp-1/CD44 monoclonal antibodies $(10 \mu \mathrm{g} / \mathrm{ml})$ alone. $15 \mu \mathrm{g}$ per lane of total RNA was subjected to Northern analysis as described in Fig. 2 and in Methods. This is a representative result of three similar experiments.

increase in IGF-1 synthesis, albeit less than that observed for hyaluronic acid (Fig. $10 \mathrm{~B}$ ). As seen with hyaluronic acid, anti$\mathrm{TNF} \alpha$ antisera inhibited the asbestos-stimulated increase in 


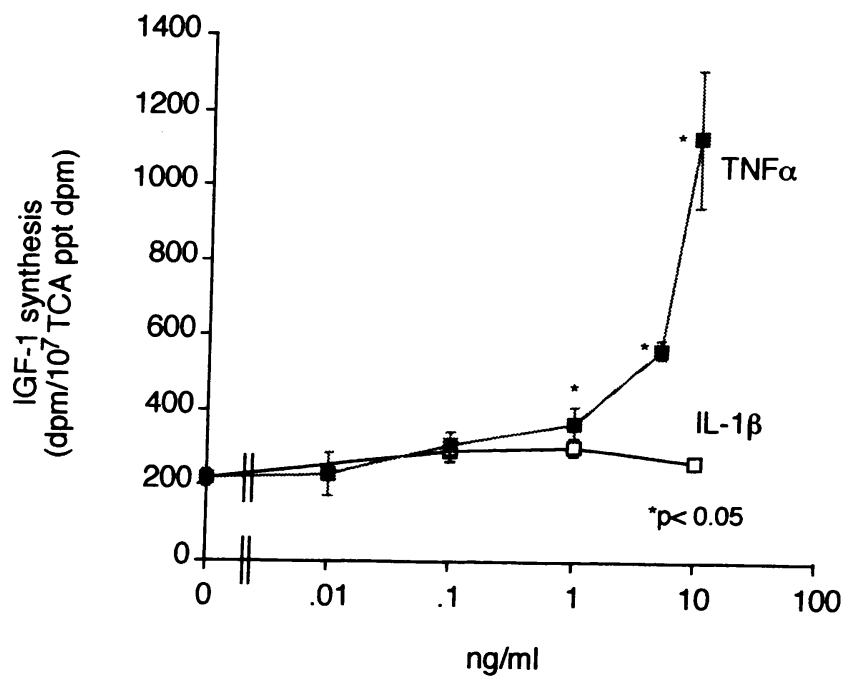

Figure 6. TNF $\alpha$ but not IL-1 $\beta$ stimulates macrophage IGF-1 protein synthesis. Macrophages were incubated with TNF $\alpha$ or IL- $1 \beta$ at the indicated concentrations for $18 \mathrm{~h}$ and IGF-1 synthesis was quantitated. These are results of four experiments.

IGF-1

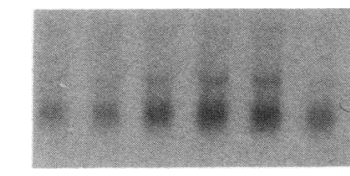

GAPDH

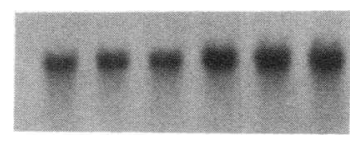

$\begin{array}{llllll}0 & 3 & 6 & 12 & 24 & 36\end{array}$

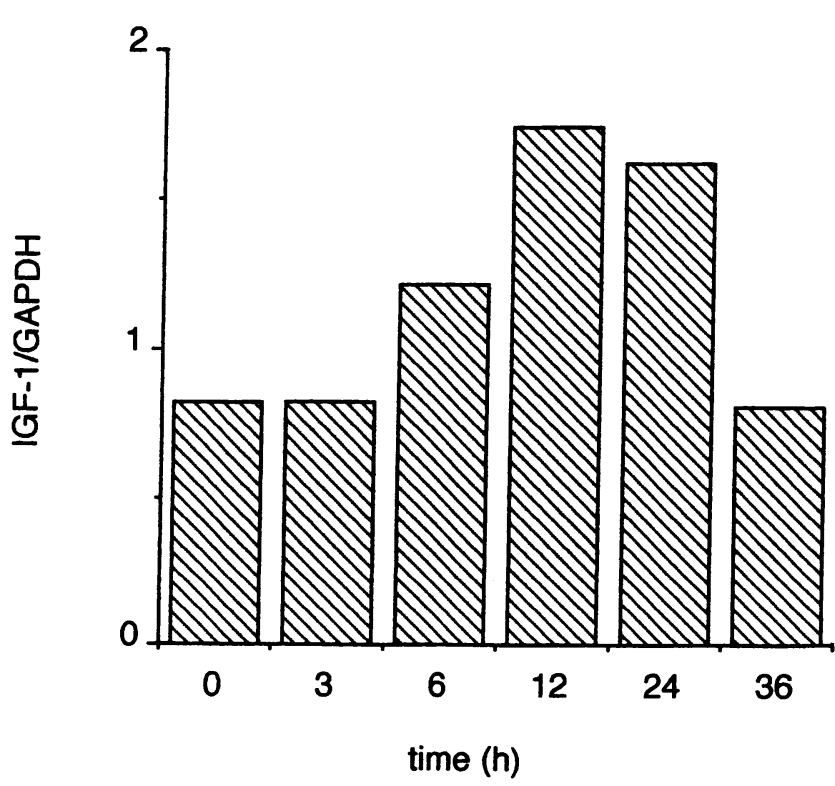

Figure 7. Autoradiographs of Northern blots showing that TNF $\alpha$ stimulates IGF-1 mRNA expression. $15 \mu \mathrm{g}$ per lane of total RNA was subjected to Northern analysis as described in Fig. 2 and in Methods. This is a representative result of three similar experiments.

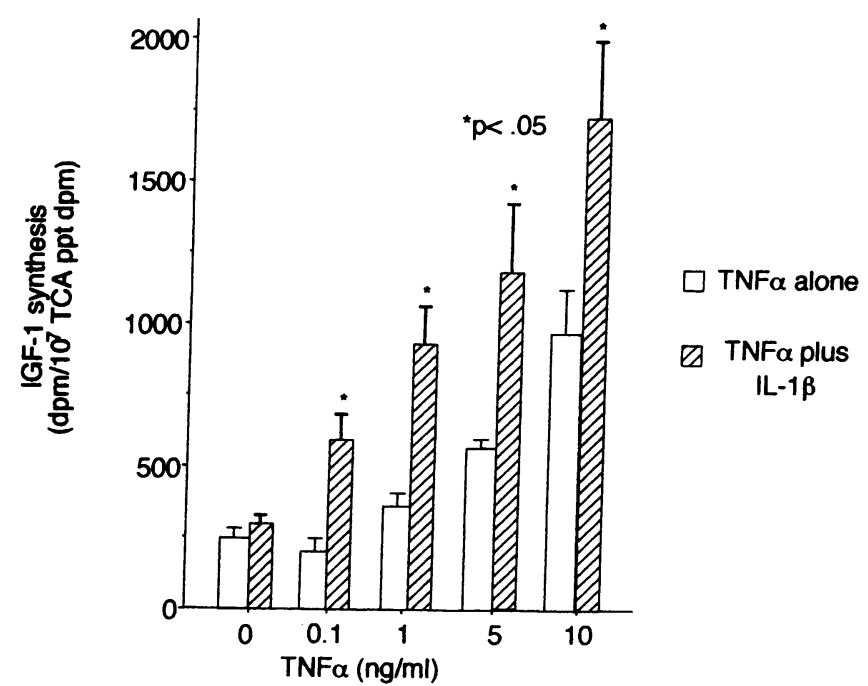

Figure 8. IL-1 $\beta$ enhances the TNF $\alpha$ stimulation of macrophage IGF-1 synthesis. Macrophages were incubated with increasing concentrations of TNF $\alpha$ (open bars) or pretreated with $10 \mathrm{ng} / \mathrm{ml}$ of IL- $1 \beta$ for $3 \mathrm{~h}$, rinsed with media, and then exposed to increasing concentrations of TNF $\alpha$ (hatched bars). IGF-1 synthesis was quantitated as described in Fig. 1 and in Methods. Results are from four experiments.

IGF-1 synthesis. However, unlike hyaluronic acid, CD44 does not appear to be involved since KM 201 antibodies had no effect on asbestos stimulation of IGF-1 (Fig. $10 \mathrm{~B}$ ). Thus hyaluronic acid and chrysotile asbestos appear to use distinct cell surface-activating mechanisms but maintain the common pathway of inducing TNF $\alpha$ production.

\section{Discussion}

In this study, we show that hyaluronic acid, a glycosaminoglycan component of extracellular matrix, induces macrophage

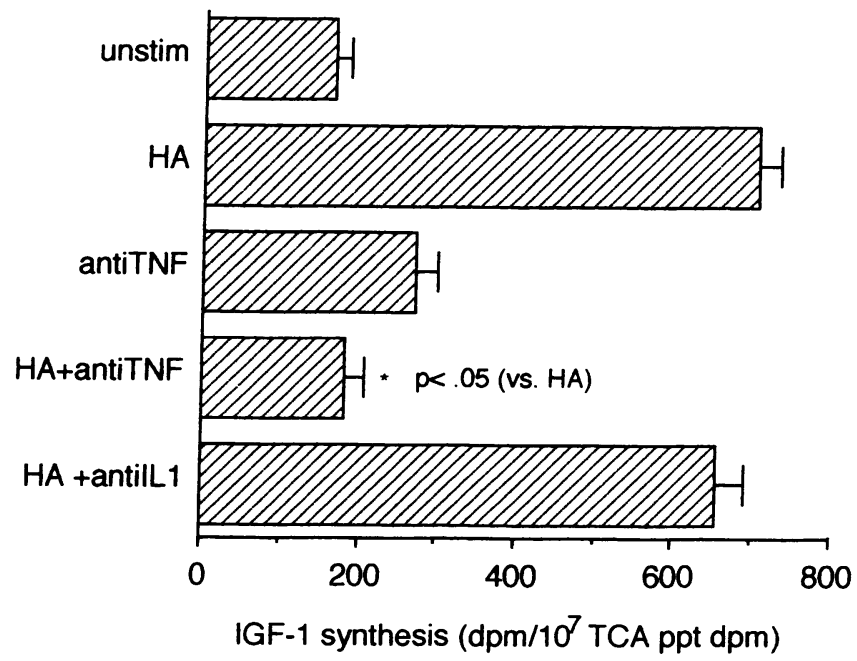

Figure 9. Anti-TNF $\alpha$ antibodies inhibit hyaluronic acid stimulation of macrophage IGF-1 synthesis. Macrophages were incubated for 18 $\mathrm{h}$ with either media alone (unstim); hyaluronic acid $(H A)$; antiTNF $\alpha$ antibodies $(10,000 \mathrm{U} / \mathrm{ml})($ antiTNF); hyaluronic acid (1 $\mathrm{mg} / \mathrm{ml})+$ anti-TNF $\alpha$ antibodies $(10,000 \mathrm{U} / \mathrm{ml})(H A+$ antiTNF $) ;$ or hyaluronic acid $(1 \mathrm{mg} / \mathrm{ml})+$ anti-IL- $\beta$ antibodies $(25 \mu \mathrm{g} / \mathrm{ml})$ $(H A+$ antilL). The $P$ value refers to the comparison between HA and $\mathrm{HA}+$ anti-TNF Ab. 


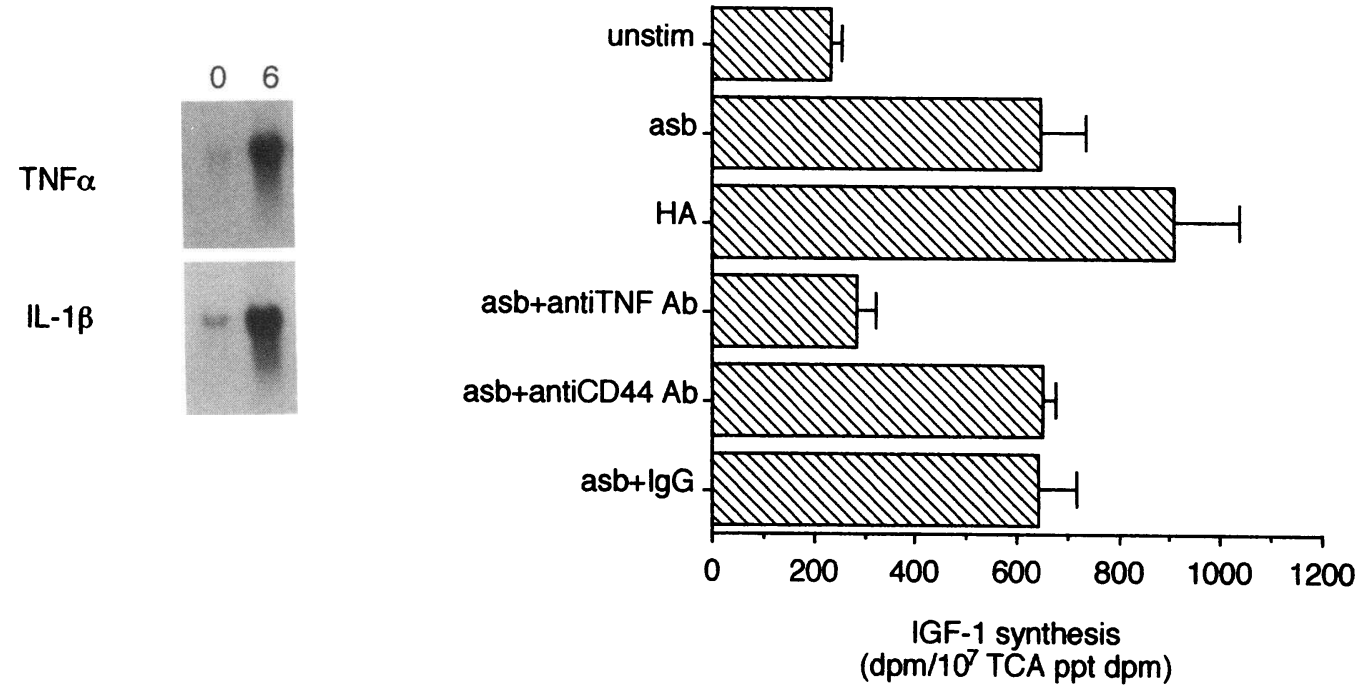
blots demonstrating that chrysotile asbestos induces IL- $1 \beta$ and TNF $\alpha$ mRNA expression. Macrophages were exposed to chrysotile asbestos ( 50 $\mu \mathrm{g} / \mathrm{ml}$ ) for $6 \mathrm{~h}$ and $15 \mu \mathrm{g}$ per lane of total RNA was isolated, subjected to $1.2 \%$ agarose-formaldehyde gel electrophoresis, transferred onto nytran membrane, and probed with ${ }^{32} \mathrm{P}$-labeled cDNA at $10^{6} \mathrm{dpm} / \mathrm{ml}$. Representative example of three experiments. ( $B$ ) Chrysotile asbestos stimulation of macrophage IGF-1 synthesis is inhibited by anti-TNF $\alpha$ antiserum but not anti-CD44 antibod-

ies. Macrophages were exposed to the following conditions for $18 \mathrm{~h}$ and IGF-1 protein synthesis quantitated: media alone (unstim); chrysotile asbestos $(50 \mu \mathrm{g} / \mathrm{ml})(a s b)$; hyaluronic acid $(1 \mathrm{mg} / \mathrm{ml})(H A) ; \operatorname{chrysotile}$ asbestos $(50 \mu \mathrm{g} / \mathrm{ml})+$ anti-TNF $\alpha$ antibodies $(10,000 \mathrm{U} / \mathrm{ml})(a s b$ + antiTNF $A b)$; chrysotile asbestos $(50 \mu \mathrm{g} / \mathrm{ml})+$ anti-Pgp-1/CD44 monoclonal antibodies $(10 \mu \mathrm{g} / \mathrm{ml})($ asb + antiCD44 Ab); and chrysotile asbestos $(50 \mu \mathrm{g} / \mathrm{ml})+$ rabbit $\operatorname{IgG}(25 \mu \mathrm{g} / \mathrm{ml})(a s b+I g G)$.

gene expression by activating the cell surface adhesion molecule CD44. Incubation of murine BMDM with soluble hyaluronic acid stimulated both IGF-1 mRNA expression and protein synthesis. Protein synthesis was stimulated fourfold while transcript levels doubled, suggesting regulation was at both transcriptional and posttranscriptional levels. Previous work with human alveolar macrophages indicated that regulation of IGF-1 production was at a posttranscriptional level since mRNA levels were equivalent in both the unstimulated and stimulated state (5). Of note, unstimulated human peripheral monocytes did not express IGF-1, indicating that the state of cell differentiation may be important (5). Multiple sizes of IGF-1 proteins from various tissues have been reported (6). We found IGF-1 reactivity in murine macrophage cell lysates to run under reducing conditions at $\sim 16-17 \mathrm{kD}$. Fibroblasts have been shown to release a $13-19-\mathrm{kD}$ preproIGF-1 A, but the biological activity has not been established (36). Further evidence that a prohormone form of IGF-1 is released was provided by Kirstein et al. (9), who demonstrated a 14-kD IGF-1 produced by monocytes that cross-reacts with antibody against IGF-1 prohormone (9).

It has been established that macrophages bind hyaluronate and possess hyaluronic acid receptors (37-39). The association of the hyaluronic acid receptor with cytoskeleton has led to a proposed role in cell adhesion and locomotion (40). CD44 is a glycoprotein expressed at a high density $\left(\sim 10^{6}\right.$ molecules per cell) on macrophages and has been shown to be present in the $\mathrm{C} 3 \mathrm{H} / \mathrm{HeJ}$ murine strain used in this study $(41,42)$. In addition to its function as a cell adhesion molecule, CD44 has recently been shown to transmit the necessary signals for release of monokines after ligation with anti-CD44 antibodies $(26,27)$. It is this concept of a link between extracellular matrix and macrophage signal transduction that is further investigated in this report.
The stimulation of macrophage-derived IGF-1 appeared to be relatively specific for hyaluronic acid since other related glycosaminoglycans did not stimulate IGF-1 production. In addition to stimulating IGF-1, hyaluronic acid also induced mRNA transcripts for both IL- $1 \beta$ and TNF $\alpha$. Evidence that hyaluronic acid was interacting with CD44 was obtained by incubating macrophages with anti-Pgp-1/CD44 monoclonal antibodies (KM 201). IGF-1, IL-1 $\beta$, and TNF $\alpha$ expression were blocked in the presence of KM 201 antibodies but not rat $\mathrm{IgG}$. The precise nature of the requirements for hyaluronate binding to CD44 have not been elucidated (43). It has recently been shown that all cells that are CD44+ do not bind hyaluronate (44). Freshly isolated murine bone marrow cells are CD44+ and do not bind hyaluronate but, when cultured for $3 \mathrm{~d}$ in IL-5, B cells acquire hyaluronate binding activity $(44,45)$. Lesley et al. (45) have suggested that hyaluronate binding may be a maturation or differentiation dependent process. There is also recent evidence that conformational changes in CD44 may be required for hyaluronate binding (43). CD44 on the surface of inflammatory macrophages undergoes posttranslational modifications including $\mathrm{N}$-linked glycosylation and phosphorylation not seen in resident cells (46). It may be that CD44 on the surface of inflammatory cells may require processing before acquiring hyaluronate binding activity. Two previous reports have demonstrated monokine production in response to soluble (28) and immobilized CD44 $(26,27)$. There are no reports that we are aware of that demonstrate soluble hyaluronic acid induced responses in IL- $1 \beta, \mathrm{TNF} \alpha$, and IGF- 1 gene expression that are blocked by anti-CD44 antibodies. Webb et al. (26) have suggested that CD44 cross-linking is required for monocyte signal transduction. We did not compare immobilized versus soluble hyaluronic acid given the marked induction of cytokine mRNA we observed. Previous studies have suggested that the large polymer nature of hyal- 
uronic acid would likely result in receptor cross-linking but this has not been confirmed $(47,48)$.

The early induction in TNF $\alpha$ and IL- $1 \beta$ mRNA in relation to IGF-1 protein suggested a possible regulatory role for these cytokines in IGF-1 production. TNF $\alpha$, but not IL- $1 \beta$, was found to directly stimulate both IGF-1 mRNA and protein production. This was consistent with the observation that TNF $\alpha$ mRNA expression peaked earlier than IL- $1 \beta$ expression. In fact, at peak IL- $1 \beta$ expression, IGF- 1 protein synthesis had already been stimulated. However, IL- $1 \beta$ was found to enhance the effect of TNF $\alpha$ on IGF-1 synthesis. Pretreatment with IL- $1 \beta$ for $3 \mathrm{~h}$ before incubation of macrophages with concentrations of TNF $\alpha$ that alone did not stimulate IGF-1 synthesis primed the cells for a TNF $\alpha$ response. Although TNF $\alpha$ has been reported to promote fibrosis $(3,4)$ and stimulate fibroblast proliferation (49), others have shown inhibition of collagen production (50). Therefore, indirect actions of TNF $\alpha$, such as stimulating the release of fibroblast growth factors that promote collagen deposition, may be important mechanisms in the fibroproliferative response. The requirement for endogenous TNF $\alpha$ production in hyaluronic acid stimulation of IGF1 was established by demonstrating inhibition of IGF- 1 synthesis in the presence of anti-TNF $\alpha$ antiserum but not anti-IL- $1 \beta$ antiserum or rabbit IgG (data not shown). Kirstein et al. (9) have provided evidence that monocyte-derived IGF-1 is not under the control of TNF $\alpha$. Human peripheral monocytes exposed to advanced glycosylation end product-modified proteins showed induction of IL- $1 \beta$, TNF $\alpha$, and IGF- 1 over a similar time course as we observed, but they did not find a requirement for endogenous TNF $\alpha$ in IGF-1 production (9). IGF-1 regulation may be related to the state of cellular differentiation since IGF-1 is not expressed in unstimulated monocytes whereas constitutive production is observed in both tissue macrophages (5) and monocyte-derived macrophages. The lack of effect of TNF $\alpha$ on monocyte IGF-1 mRNA expression may be due to a species difference or a concentration dependence, since they did not observe an effect evident at $10 \mathrm{pg} / \mathrm{ml}$. The lowest concentration at which we observed an effect on IGF-1 expression was $1 \mathrm{ng} / \mathrm{ml}$. A more interesting possibility is that the TNF $\alpha$ response is also differentiation dependent. There is evidence to suggest that macrophages exhibit different responses to TNF $\alpha$ depending on both the time in culture and whether differentiation occurs in CSF-1 or GM-CSF (51). This has been postulated to be related to differential expression and signaling through the type I (55-60-kD) and II (75-80-kD) TNF receptors $(51,52)$.

To further assess the role of CD44 and TNF $\alpha$ in IGF-1 production, we used another known stimulator of macrophage-derived IGF-1, chrysotile asbestos $(5,10)$. We found that asbestos stimulated IL- $1 \beta$, TNF $\alpha$, and IGF-1 production as did hyaluronic acid, although the IGF-1 stimulation by asbestos was less pronounced. It is likely that the amount of IGF1 produced is sufficient to stimulate fibroblast proliferation since Rom et al. ( 5 ) purified IGF-1 from supernatants of asbestos-stimulated macrophages that provided progression activity in a fibroblast complementation assay. Asbestos stimulated IGF-1 independent of CD44 since the KM 201 antibodies had no effect on IGF-1 synthesis. Interestingly, endogenous TNF $\alpha$ also proved essential for asbestos stimulation of IGF-1 since anti-TNF $\alpha$ antiserum blocked IGF-1 protein synthesis. Thus, for two distinct stimuli that activate macrophages through dif- ferent cell surface mechanisms, TNF $\alpha$ production is a common step that is necessary for macrophage IGF-1 production.

The results of this study show that hyaluronic acid stimulates macrophage-derived IGF-1 by activating the cell surface adhesion molecule CD44, and this pathway requires TNF $\alpha$ production. Increased amounts of hyaluronic acid have been demonstrated in several animal models of inflammatory tissue injury as well as disease states such as pulmonary fibrosis (1416 ). Increased production of hyaluronic acid is an early event in connective tissue reparative processes associated with wound healing $(53,54)$. Since hyaluronate is also a constituent of the normal extracellular matrix, as well as being present in large quantities in synovial fluid, there must be a mechanism preventing chronic activation of inflammatory cells. This may be regulated at the level of hyaluronate binding by CD44 since freshly isolated bone marrow cells as well as resting B cells express CD44 but do not bind hyaluronate $(44,45)$. After culture with CSF-1 for $5 \mathrm{~d}$, monocyte-derived macrophages respond to hyaluronate. This appears similar to the effect of IL-5 on B cells (44). Very recent data have increased the known CD44 isoforms to 15 , and the specificity of their expression and hyaluronate binding capacities have not been determined (55). Upregulation of CD44 has been demonstrated in synovial tissue from patients with rheumatoid arthritis ( 56). Immunofluorescent staining with anti-CD44 monoclonal antibodies showed increased CD44 expression on infiltrating lymphocytes, macrophages, as well as synovial lining cells, vessels, and fibroblasts that was not observed in noninflammatory tissue (56). Thus, in addition to conformational changes in CD44 or distinct binding capacities of different isoforms, a significant upregulation in CD44 expression may be required to maintain the inflammatory focus. The structure of the hyaluronate may also influence binding by CD44. In normal synovial fluid, hyaluronate exists in a high molecular weight form that is the major contributor to the high viscosity of synovial fluid (57). In rheumatoid arthritis synovial fluid, the hyaluronate concentration is decreased and the hyaluronate is depolymerized into lower molecular weight forms. In one study, high molecular weight hyaluronate was shown to inhibit whereas low molecular weight forms enhanced macrophage phagocytosis (57). The effects of hyaluronate molecular weight on binding to macrophage CD44 have not been investigated, but depolymerization of hyaluronate as occurs in inflammation may be required to facilitate binding and signal transduction.

Recently, several published reports have strongly implicated TNF $\alpha$ as playing a critical role in the pathogenesis of both pulmonary fibrosis and granulomatous inflammation in murine models $(3,4)$. These conditions have in common the recruitment and proliferation of fibroblasts. Although numerous "fibrogenic" mediators released by macrophages have been identified, the endogenous or "physiological" stimuli that trigger their release have remained elusive. One possibility is that matrix components generated during the inflammatory response may interact with monocyte/macrophages, stimulate cytokine and growth factor production, and drive the fibroproliferative response. Monocyte/macrophages cultured on extracellular component matrices exhibit enhanced phagocytosis, bactericidal activity, and alterations in inflammatory gene expression (58-60). Although the precise etiologic role of IGF-1 in promoting pulmonary fibrosis has not been established, wound macrophages also express IGF-1 mRNA and IGF-1 
promotes wound repair, suggesting a role in scar formation $(61,62)$.

The data presented herein support the hypothesis that hyaluronic acid stimulates macrophage gene expression by activating CD44. Additional data are put forth suggesting that TNF $\alpha$ may exert some of its described fibroproliferative activity by stimulating the production of macrophage IGF-1. Finally, these results support the concept that extracellular matrix components generated during the inflammatory response may play a direct role in regulating the repair process through effects on macrophage cytokine and growth factor expression. A ratelimiting step driving the repair process may be the continued production of matrix components such as hyaluronic acid. The characterization of the effects of specific matrix-cell interactions on inflammatory gene regulation will help identify critical sites to attempt interruption of signal transduction pathways and potentially abrogate the excessive fibroproliferative response characteristic of fibrotic disorders.

\section{Acknowledgments}

We thank Dr. P. W. Kincade for graciously supplying KM 201 antiPgp-1/CD44 monoclonal antibodies as well as helpful comments regarding the manuscript. We also thank Dr. Peter Rotwein for generously supplying the murine IGF-1 cDNA, Dr. Arjin Singh for supplying the murine IL- $1 \beta$ and TNF $\alpha$ cDNA, and Dr. John Shannon for the human GAPDH cDNA. We also appreciate the technical support of Lori Sanders and Linda Remigio.

This work was supported by Public Health Service grant HL-27353. This work was done during the tenure of a clinician scientist award from the American Heart Association (P. W. Noble)

\section{References}

1. Rappolee, D. A., and Z. Werb. 1988. Secretory products of phagocytes. Curr. Opin. Immunol. 1:47-55.

2. Amiri, P., R. M. Locksley, T. G. Parslow, M. Sadick, E. Rector, D. Ritter, and J. H. McKerrow. 1992. Tumour necrosis factor $\alpha$ restores granulomas and induces parasite egg-laying in schistosome-infected SCID mice. Nature (Lond.). 356:604-607.

3. Piguet, P. F., M. A. Collart, G. E. Grau, A.-P. Sappino, and P. Vassalli. 1990. Requirement of tumour necrosis factor for development of silica-induced pulmonary fibrosis. Nature (Lond.). 344:245-247.

4. Piguet, P. F., M. A. Collart, G. E. Grau, Y. Kapanci, and P. Vassalli. 1989 Tumor necrosis factor/cachectin plays a key role in bleomycin-incuded pneumopathy and fibrosis. J. Exp. Med. 170:655-663.

5. Rom, W. N., P. Basset, G. A. Fells, T. Nukiwa, B. C. Trapnell, and R. G Crystal. 1989. Alveolar macrophages release an insulin-like growth factor 1-type molecule. J. Clin. Invest. 82:1685-1693.

6. Sara, V. R., and K. Hall. 1990. Insulin-like growth factors and their binding proteins. Physiol. Rev. 70:591-614.

7. Stiles, C. D., G. T. Capone, C. D. Scher, H. N. Antoniades, J. J. Van Wyk, and W. J. Pledger. 1979. Dual control of cell growth by somatomedins and platelet-derived growth factor. Proc. Natl. Acad. Sci. USA. 76:1279-1283.

8. Bitterman, P. B., S. I. Rennard, G. W. Hunninghake, and R. G. Crystal. 1983. Human alveolar macrophage growth factor for fibroblasts: regulation and partical purification. J. Clin. Invest. 70:806-822

9. Kirstein, M., C. Aston, R. Hintz, and H. Vlassara. 1992. Receptor-specific induction of insulin-like growth factor 1 in human monocytes by advanced glycosylation end product-modified proteins. J. Clin. Invest. 90:439-446.

10. Noble, P. W., P. M. Henson, and D. W. H. Riches. 1991. IGF-1 mRNA expression in bone marrow-derived macrophages is stimulated by chrysotile asbestos. A potential marker for macrophage phenotypic differentiation. Chest. 99:79S-80S.

11. Abboud, S. L., C. B. Bethel, and D. C. Aron. 1991. Secretion of insulinlike growth factor I and insulin-like growth factor-binding proteins by murine bone marrow stromal cells. J. Clin. Invest. 88:470-475.

12. Alexander, C. M., and Z. Werb. 1989. Proteinases and extracellular remodeling. Curr. Opin. Cell Biol. 1:974-982.

13. Rennard, S. I., G. W. Hunninghake, P. B. Bitterman, and R. G. Crystal.
1981. Production of fibronectin by the human alveolar macrophage: mechanism for the recruitment of fibroblasts to sites of tissue injury in interstitial lung diseases. Proc. Nat. Acad. Sci. USA. 78:7147-7151.

14. Bjermer, L., R. Lundgren, and R. Hallgren. 1989. Hyaluron and type III procollagen peptide concentrations in bronchoalveolar lavage fluid in idiopathic pulmonary fibrosis. Thorax. 44:126-131.

15. Nettelbladt, O., J. Bergh, M. Schenholm, A. Tengblad, and R. Hallgren 1988. Accumulation of hyaluronic acid in the alveolar interstitial tissue in bleomycin-induced alveolitis. Am. Rev. Respir. Dis. 139:759-762.

16. Nettelbladt, O., and R. Hallgren. 1989. Hyaluron (hyaluronic acid) in bronchoalveolar lavage fluid during the development of bleomycin-induced alveolitis in the rat. Am. Rev. Respir. Dis. 140:1028-1032.

17. Postlethwaite, A. E., G. N. Smith, Jr., L. B. Lachman, R. O. Endres, H. M. Poppleton, K. A. Hasty, J. M. Seyer, and A. H. Kang. 1989. Stimulation of glycosamonoglycan synthesis in cultured human dermal fibroblasts by interleukin 1. J. Clin. Invest. 83:629-636.

18. Haynes, B. F., M. J. Telen, L. P. Hale, and S. M. Denning. 1989. CD44, a molecule involved in leukocyte adherence and $\mathrm{T}$ cell activation. Immunol. To day. 10:423-428

19. Butcher, E. C. 1990. Cellular and molecular mechanisms that direct leukocyte traffic. Am. J. Pathol. 136:3-11.

20. Werb, Z., P. M. Tremble, O. Behrendtsen, E. Crowley, and C. H. Damsky 1989. Signal transduction through the fibronectin receptor induces collagenase and stromelysin gene expression. J. Cell Biol. 109:877-889.

21. Aruffo, A., I. Stamenkovic, M. Melnick, C. B. Underhill, and B. Seed. 1990. CD44 is the principal cell surface receptor for hyaluronate. Cell. 61:13031313.

22. Miyake, K., C. B. Underhill, J. Lesley, and P. W. Kincade. 1990. Hyaluronate can function as a cell adhesion molecule and CD44 participates in hyaluronate recognition. J. Exp. Med. 172:69-75.

23. Bazil, B., and V. Horejsi. 1992. Shedding of the CD44 adhesion molecule from leukocytes induced by anti-CD44 monoclonal antibody simulating the effect of a natural receptor ligand. J. Immunol. 149:747-753.

24. Wolffe, E. J., W. C. Gause, C. M. Pelfrey, S. M. Holland, A. D. Steinberg, and J. T. August. 1990. The cDNA sequence of mouse Pgp-1 and homology to human CD44 cell surface antigen and proteoglycan core/link proteins. J. Biol Chem. 265:341-347.

25. Miyake, K., K. L. Medina, S.-I. Hayashi, S. Ono, T. Hamaoka, and P. W Kincade. 1990. Monoclonal antibodies to Pgp-1 /CD44 block lymphohemopoiesis in long-term bone marrow cultures. J. Exp. Med. 171:477-488.

26. Webb, D. S. A., Y. Shimizu, G. A. Van Seventer, S. Shaw, and T. I. Gerrard. 1990. LFA-3, CD44, and CD45: physiologic triggers of human monocyte TNF and IL-1 release. Science (Wash. DC). 249:1295-1297.

27. Gruber, M. F., D. S. A. Webb, and T. L. Gerrard. 1992. Stimulation of human monocytes via CD45, CD44, and LFA-3 triggers macrophage-colony stimulating factor production. J. Immunol. 148:1113-1118.

28. Denning, S. M., P. T. Le, K. H. Singer, and B. F. Haynes. 1990. Antibodies against the CD44 p80, lymphocyte homing receptor molecule augment human peripheral blood T cell activation. J. Immunol. 144:7-14.

29. Riches, D. W. H., and G. A. Underwood. 1991. Expression of IFN $\beta$ during the triggering phase of macrophage cytocidal activation. Evidence for an autocrine/paracrine role in the regulation of this state. J. Biol. Chem. 266:24785-24792.

30. Chirgwin, J. M., R. J. Przbyla, R. J. MacDonald, and W. J. Rutter. 1979. Isolation of biologically active ribonucleic acid from sources enriched in ribonuclease. Biochemistry. 18:5294-5299.

31. Thomas, P. 1980. Hybridization of denatured RNA and small DNA fragments transferred to nitrocellulose. Proc. Natl. Acad. Sci. USA. 77:5201-5205.

32. Hiro, D., A. Ito, K. Matsuta, and Y. Mori. 1986. Hyaluronic acid is an endogenous inducer of interleukin-1 production by human monocytes and rabbit macrophages. Biochem. Biophys. Res. Commun. 140:715-722.

33. Lesley, J., R. Shulte, and R. Hyman. 1990. Binding of hyaluronic acid to lymphoid cell lines is inhibited by monoclonal antibodies against Pgp-1. Exp. Cell Res. 187:224-231.

34. Le, J., and J. Vilcek. 1987. Biology of disease. Tumor necrosis factor and interleukin-1: cytokines with multiple overlapping biological activities. Lab. In vest. 56:234-243.

35. Dubois, C. M., E. Bissoninette, and M. Rola-Pleszczynski. 1989. Asbestos fibers and silica particles stimulate rat alveolar macrophages to release tumor necrosis factor. Am. Rev. Respir. Dis. 139:1257-1264.

36. Conover, C. A., B. K. Baker, and R. L. Hintz. 1989. Cultured human fibroblasts secrete insulin-like growth factor IA prohormone. J. Clin. Endocrinol. Metab. 69:25-30.

37. Green, S. J., G. Tarone, and C. B. Underhill. 1988. Aggregation of macrophages and fibroblasts is inhibited by a monoclonal antibody to the hyaluronate receptor. Exp. Cell Res. 178:224-232.

38. Green, S. J., G. Tarone, and C. B. Underhill. 1988. Distribution of hyaluronate and hyaluronate receptors in the adult lung. J. Cell Sci. 89:145-156.

39. Shannon, B. T., S. H. Love, and Q. N. Myrvik. 1980. Participation of 
hyaluronic acid in the macrophage disappearance reaction. Immunol. Commun. 9:357-370.

40. Lacy, B. E., and C. B. Underhill. 1987. The hyaluronate receptor is associated with actin filaments. J. Cell Biol. 105:1395-1404.

41. Hughes, E. N., G. Mengod, and J. T. August. 1981. Murine cell surface glycoproteins. Characterization of a major component of 80,000 daltons as a polymorphic differentiation antigen of mesenchymal cells. J. Biol. Chem. 256:7023-7027.

42. Hughes, E. N., A. Colombatti, and J. T. August. 1983. Murine cell surface glycoproteins. Purification of the polymorphic Pgp-1 antigen and analysis of its expression on macrophages and other myeloid cells. J. Biol. Chem. 258:10141021.

43. Lesley, J., Q. He, K. Miyake, A. Hamann, R. Hyman, and P. W. Kincade. 1992. Requirements for hyaluronic acid binding by CD44. A role for the cytoplasmic domain and activation by antibody. J. Exp. Med. 175:257-266.

44. Murakami, S., K. Miyake, C. H. June, P. W. Kincade, and R. J. Hodes. 1990. IL-5 induces a Pgp-1 (CD44) bright B cell subpopulation that is highly enriched in proliferative and Ig secretory activity and binds to hyaluronate. $J$. Immunol. 145:3618-3627.

45. Lesley, J., and R. Hyman. 1992. CD44 can be activated to function as an hyaluronic acid receptor in norman murine T cells. Eur. J. Immunol. 22:27192723.

46. Camp, R. L., T. A. Kraus, and E. Pure. 1991. Variations in the cytoskeletal interaction and posttranslational modification of the CD44 homing receptor in macrophages. J. Cell Biol. 115:1283-1292.

47. Underhill, C. B., and B. P. Toole. 1979. Binding of hyaluronate to the surface of cultured cells. J. Cell Biol. 82:475-484.

48. Underhill, C. B., A. L. Thurn, and B. E. Lacy. 1985. Characterization and identification of the hyaluronate binding site from membranes of SV-3T3 cells. $J$. Biol. Chem. 260:8128-8133.

49. Vilcek, J., V. J. Palombella, D. E. Henriksen-DeStefano, C. Swenson, R. Feinman, M. Hirai, and M. Tsujimoto. 1986. Activity of tumor necrosis factor and its relationship to other polypeptide growth factors. J. Exp. Med. 163:632643 .
50. Solis-Herruzo, J. A., D. A. Brenner, and M. Chojkier. 1988. Tumor necrosis factor $\alpha$ inhibits collagen gene transcription and collagen synthesis in cultured human fibroblasts. J. Biol. Chem. 263:5841-5845.

51. Witsell, A. L., and L. B. Schook. 1992. Tumor necrosis factor $\alpha$ is an autocrine growth regulator during macrophage differentiation. Proc. Natl. Acad. Sci. USA. 89:4754-4758.

52. Tartaglia, L. A., R. F. Weber, I. S. Figari, C. Reynolds, M. A. Palladino, and D. V. Goedell. 1991. The two different receptors for tumor necrosis facto mediate distinct cellular responses. Proc. Natl. Acad. Sci. USA. 88:9292-9296.

53. Hasty, K. A., G. N. Smith, Jr., and A. H. Kang. 1981. Studies on glycosaminoglycans of regenerating rabbit ear cartilage. Dev. Biol. 86:198-206.

54. Alexander, S. A., and R. B. Donoff. 1980. The glycosaminoglycans of open wounds. J. Surg. Res. 29:422-429.

55. He, Q., J. Lesley, R. Hyman, K. Ishihara, and P. W. Kincade. 1992. Molecular isoforms of murine CD44 and evidence that the membrane proximal domain is not critical for hyaluronate recognition. J. Cell Biol. 119:1711-1719.

56. Haynes, B. F., L. P. Hale, K. L. Patton, M. E. Martin, and R. M. McCallum. 1991. Measurement of an adhesion molecule as an indicator of inflammatory disease activity. Up-regulation of the receptor for hyaluronate (CD44) in rheumatoid arthritis. Arthritis Rheum. 34:1434-1443.

57. Forrester, J. V., and E. A. Balazs. 1980. Inhibition of phagocytosis by high molecular weight hyaluronate. Immunology. 40:435-446.

58. Newman, S. L., and M. A. Tucci. 1990. Regulation of human monocyte/ macrophage function by extracellular matrix. J. Clin. Invest. 86:703-714

59. Nathan, C., and M. Sporn. 1991. Cytokines in context. J. Cell Biol. 113:981-986.

60. Eierman, D. F., C. E. Johnson, and J. S. Haskill. 1989. Human monocyte inflammatory mediator gene expression is selectively regulated by adherence substrates. J. Immunology. 142:1970-1976.

61. Lynch, S. E., R. B. Colvin, and H. N. Antoniades. 1989. Growth factors in wound healing. J. Clin. Invest. 84:640-646.

62. Rappolee, D. A., D. Mark, M. J. Banda, and Z. Werb. 1988. Wound macrophages express TGF-alpha and other growth factors in vivo: analysis by mRNA phenotyping. Science (Wash. DC). 241:708-712. 